\title{
Seasonal variation in fish trophic networks in two clear-water streams in the Central Llanos region, Venezuela
}

\author{
Christopher C. Peterson ${ }^{1}$, Friedrich W. Keppeler ${ }^{2}$, David E. Saenz ${ }^{2}$, Luke M. Bower ${ }^{2}$ and \\ Kirk O. Winemiller ${ }^{2}$
}

Food webs are not static entities; consumer resource interactions vary in both time and space, which complicates depiction and comparisons of food web structures. We estimated fish assemblage structure and diets in two clear-water streams in the Venezuelan Llanos region (Charcote and Charcotico) and constructed trophic networks (sub-webs defined by fishes as the principal consumers) during four periods of the annual flood pulse. As stream conditions changed from high-water to low-water, we hypothesized that: 1) the piscivore-non-piscivore ratio would increase; 2) dietary diversity would decrease; 3 ) interspecific dietary overlap would decline; 4) fewer allochthonous food items would be consumed; and 5) food-web connectance would increase. The piscivore-non-piscivore abundance ratio was higher in both streams during the low-water period. Dietary diversity declined as water levels dropped and availability of aquatic habitats and resources declined, but interspecific dietary overlap was not lower. Contrary to our hypothesis, average interspecific dietary overlap increased at Charcote as the dry season progressed, even though dietary overlap among species was significantly lower than expected by chance. We did not find strong support for our hypotheses regarding seasonal patterns of consumption of allochthonous resources and food web connectance, both of which revealed little seasonal variation.

Keywords: Aquatic ecosystem, Flood pulse, Predation, Predator-prey interactions, Trophic niche.

Redes alimentares não são entidades estáticas; interações entre consumidores e recursos variam no tempo e no espaço, o que complica as representações das estruturas de redes alimentares. Nós estimamos a estrutura da assembléia de peixes e dieta em dois riachos de água clara na região venezuelana dos Llanos (Charcote e Charcotico) e construímos redes tróficas (sub-redes definidas por peixes como os principais consumidores) para quatro períodos do pulso anual de inundação. À medida que as condições dos riachos mudam de águas altas para águas baixas, nós hipotetizamos que: 1) a razão piscívoros e não piscívoros irá aumentar; 2) a diversidade da dieta irá diminuir; 3) a sobreposição alimentar interespecífica irá diminuir; 4) menos itens alimentares alóctones serão consumidos; e 5) a conectância da teia alimentar irá aumentar. A razão da abundância de piscívoros e não piscívoros foi maior em ambos riachos durante a estação de águas baixas. A diversidade da dieta declinou à medida que as águas baixavam e a disponibilidade de habitats aquáticos e recursos declinavam, mas a sobreposição alimentar interespecífica não foi menor. Contrária à nossa hipótese, a média de sobreposição alimentar interespecífica aumentou no Charcote à medida que a estação cheia progrediu, mesmo com a sobreposição alimentar significativamente menor do que o esperado ao acaso. Não encontramos forte suporte para nossas hipóteses relacionadas aos padrões sazonais de consumo de recursos alóctones e conectância da cadeia trófica, os quais revelaram pouca variação sazonal.

Palavras-chave: Ecossistema aquático, Interações predador-presa, Nicho trófico, Predação, Pulso de inundação.

\section{Introduction}

Over the past four decades, considerable effort has been expended to describe empirical food webs (Cohen et al., 1993) and create models that can describe their features (Williams, Martinez, 2000); however, this has not been without controversy (Rooney et al., 2008). Description of even the most species-poor systems and static systems is a major challenge that would require time- and labor- intensive methodologies, such as analysis of gut contents or observation of feeding events for thousands of individual organisms and hundreds of species comprising a local community. Most empirical food webs that have been analyzed are very simple depictions of what actually are large, complex systems (Polis, 1991). The great majority of published food webs are based on information obtained by unspecified methods and time periods (Polis, 1991; Yodzis, Winemiller, 1999; McMeans et al., 2015).

${ }^{1}$ Community Medical Associates, 76904 San Angelo, Texas, USA. peterson@tamu.edu

${ }^{2}$ Department of Wildlife and Fisheries Sciences, and Interdisciplinary Program in Ecology and Evolutionary Biology, Texas A\&M University, 77843 College Station, Texas, USA. (FWK) fkeppeler@gmail.com (corresponding author), (DEAS) dsaenz@tamu.edu, (LMB)lbower88@tamu.edu, (KOW)k-winemiller@tamu.edu 
Animals often shift their diets in response to changes in resource availability (Buren et al., 2012), abiotic environmental conditions (Stuart-Smith et al., 2004), ontogenetic stage (Werner, Hall, 1988), competition (Kie, Bowyer, 1999), and interactions with predators or parasites (Thompson, Townsend, 1999; Siepielski et al., 2016). Consequently, food web structure (the architecture of networks of consumer-resource interactions) varies in both space and time (Winemiller, 1990; McCann, 2011). Given the considerable challenges to describe a network of predator-prey interactions, even one involving a subset of species within a local community, few studies have attempted to document food web structure across gradients of space or time (McMeans et al., 2015).

Here we investigate temporal change in food web structure based on a field study of two streams in the South American Llanos (Orinoco Basin). Seasonal variation in precipitation is one of the most important factors influencing fish assemblages in tropical rivers and streams (Junk et al., 1989). During the wet season, water bodies expand into floodplains where fishes can exploit habitats suitable for spawning, feeding, and refuge from predators (Winemiller, Jepsen, 1998). Aquatic floodplain habitats generally support high primary and secondary production and diverse resources, including allochthonous foods such as fruits, seeds, and terrestrial invertebrates (Goulding et al., 1988; Henderson, 1990; Correa, Winemiller, 2014). During the dry season, aquatic floodplain habitats shrink, fish densities increase within more permanent water bodies, and availability of many food resources declines (Winemiller, Jepsen, 1998).

When seasonal reduction in habitats results in higher consumer densities and resource depletion, both dietary breadth and interspecific dietary overlap should decline as a result of niche compression to reduce interspecific competition. These are conditions that tend to occur in tropical streams and rivers during the dry season (Zaret, Rand, 1971; Winemiller, 1989; Mérona, Rankin-deMérona, 2004). In contrast, optimal foraging theory (Emlen, 1966; Schoener, 1971) would predict low dietary breadth with high overlap when resources are abundant and diverse allowing consumers select the most profitable food resources. These conditions may occur during the annual flood pulse in tropical river floodplains (Correa, Winemiller, 2014). Higher fish densities resulting from habitat compression during the low-water season generally increases the frequency of encounters between predatory fishes and their prey (Arrington et al., 2005), which should result in increased food web connectance (Winemiller, 1990; Winemiller et al., 2001). In regions where isolated pools are formed during the dry season, the ratio of predator to prey abundance increases if reproductive rates of prey are insufficient to offset predation mortality (Winemiller, 1989; Winemiller, Jepsen, 1998).

We compared networks of fish trophic interactions (i.e., fish-centric food webs) in two clear-water streams during four periods of the annual wet-dry seasonal cycle in the Central Llanos region of Venezuela. We tested five hypotheses about changes that should occur as the dry season ensues and aquatic habitats shrink: 1) the ratio of piscivorous fish abundance to non-piscivore abundance increases because prey populations (mostly represented by non-piscivorous fishes) suffer increasing mortality as encounters between predators and prey increase; 2) average dietary diversity and 3) interspecific dietary overlap both decline as fish densities increase, food resources become increasingly scarce, and competition intensifies; 4) relatively fewer allochthonous food resources are consumed by fishes as water recedes from the floodplain; and 5) food web connectance increases as predator-prey interactions intensify. We also examined seasonal variation in fish assemblage structure and its relationship with assemblage-wide patterns of food resource utilization.

\section{Material and Methods}

Study area. The Central Llanos (plains lying north and northwest of the Orinoco River in Venezuela) contains extensive floodplains with strongly seasonal dynamics and diverse fish assemblages. Fishes from this region have diverse morphological, physiological, and behavioral adaptations that promote fitness and population persistence in dynamic environments within heterogeneous landscapes (Lowe-McConnell, 1987). As the rains begin and water levels rise (typically during late May), local fish assemblages in floodplain streams are comprised of resistant species that remained within isolated aquatic floodplain habitats under harsh dryseason conditions plus recent immigrants from nearby streams and rivers that maintain flow year-round and thus serve as dry-season refugia for less resistant species (Winemiller, 1996). At the beginning of the wet season, fish densities are low within expanding aquatic habitats in floodplains, but bursts of reproduction soon increase population abundance of virtually all species (LoweMcConnell, 1987). During the dry season, aquatic floodplain habitats shrink and many become isolated. Many fishes emigrate to more permanent water bodies, but others remain in drying floodplain pools and channels. Fish densities increase within shrinking water bodies, and mortality often is high due to harsh abiotic conditions and predation (Winemiller, 1996).

Study sites were stream reaches within two tributaries of the Río San Bartolo, itself a tributary of the Río Guariquito in the Central Llanos region (estado Guarico): Morichal Charcote, referred to as Charcote hereafter, at approximately $08^{\circ} 06^{\prime} 7.20^{\prime \prime} \mathrm{N} 66^{\circ} 40^{\prime} 48.00^{\prime \prime} \mathrm{W}$, and Morichal Charcotico, referred to as Charcotico hereafter, at $08^{\circ} 09^{\prime} 36.00^{\prime \prime N} 66^{\circ} 46^{\prime} 15.60^{\prime \prime W}$ (Fig. 1). Both streams are located within the Aguaro-Guariquito National Park, a 569,000 ha protected zone encompassing grassland 
and open woodland ecosystems on relatively flat terrain (Montes et al., 2013). Regional precipitation averages $1200 \mathrm{~mm} / \mathrm{yr}$, with most rainfall occurring from June through November. During the wet season, Llanos streams and rivers spill water onto expansive floodplains (Winemiller, 1989). Floodwater recession begins during December and continues until May, which corresponds with the dry season when there is little precipitation.

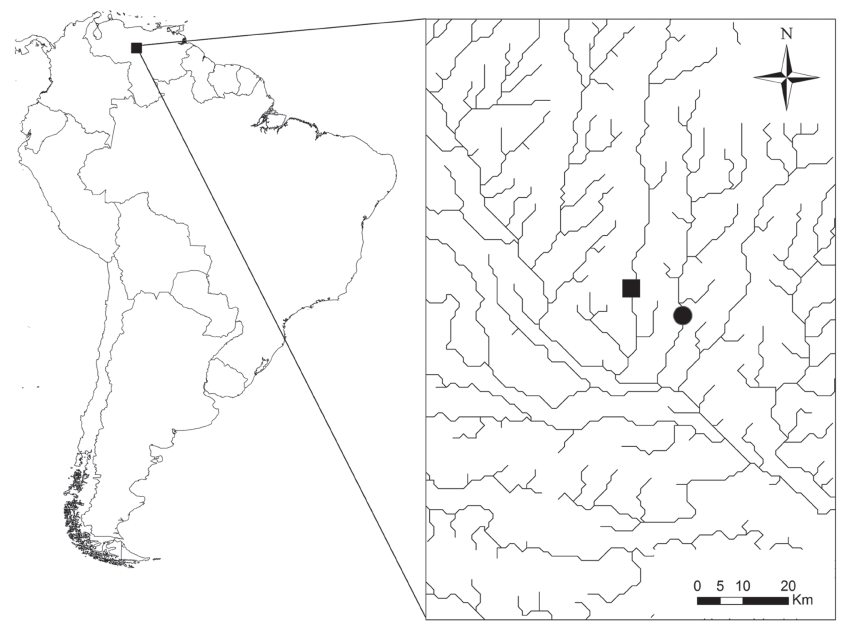

Fig. 1. Map showing locations of the two streams in the Llanos of the Orinoco Basin, Venezuela, Charcote (black dot) and Morichal Charcotico (black square), where fish trophic networks were studied.

During September (late wet season), the Charcotico channel width averaged $c a .2 .5 \mathrm{~m}$, and one large pool that was surveyed measured $75 \mathrm{~m} \mathrm{x} 47 \mathrm{~m}$ (max depth $1.22 \mathrm{~m}$ ). Leaf litter from riparian trees formed a layer about $5-\mathrm{cm}$ thick on the pool bottom. The underlying substrate was mostly sand, with gravel increasing toward the middle of the channel where there was more current. Charcotico was shallower than Charcote (Tab. 1), but flooded more extensively into the surrounding plains (flooding was from June-November). By January, the receding water divided the large pool into two. The channel width of Charcote averaged $2 \mathrm{~m}$, and our study reach had a pool measuring $c a .24 \mathrm{~m} \times 20 \mathrm{~m}$ with a maximum depth of $3 \mathrm{~m}$. Compared to Charcotico, fewer trees lined the banks of Charcote and leaf litter was sparse. Charcote's substrate was predominately sand with patches of gravel and exposed bedrock, and, unlike Charcotico, shallow areas of the pool perimeter supported aquatic macrophytes.

Sampling procedures. Four surveys were conducted at each study site between September 1995 and January 1996. Each of these 5 -day surveys was separated by 6 weeks so that removal of fish would not influence patterns of fish abundance during the subsequent survey at the site. Survey periods were as follows: September (high water), November (falling water) December (falling water) and January (low water). During each survey at each site, water quality data were collected using a Hach ${ }^{\circledR}$ limnology kit to measure $\mathrm{pH}$ and dissolved oxygen. Water and air temperatures were recorded with a thermometer. Maximum water depth and secchi depth (water transparency) were recorded at each site during each survey. Percentages of the wetted channel area covered by tree canopy and submerged aquatic vegetation were visually estimated. Physical and chemical variables recorded at study sites are summarized in Tab. 1.

During each survey, fishes were collected daily using seines, experimental gill nets, and cast nets. In order to catch both diurnal and nocturnal fishes, two seines (each was $2.5 \mathrm{~m} \mathrm{x} 4 \mathrm{~m}$, but one with $3.2 \mathrm{~mm}$ mesh and one with $12.7 \mathrm{~mm}$ mesh) were used at each site for $2 \mathrm{~h}$ after dawn, and $2 \mathrm{~h}$ after dusk, and the cast net $(1.5 \mathrm{~m}$ diameter, $2.5 \mathrm{~mm}$ mesh) was used during afternoon and night. Experimental gill nets were placed within pools in a line perpendicular to the current from dusk until sunrise. Captured fish specimens were euthanized by MS222 overdose then preserved in $15 \%$ formalin. Incisions were made into the body cavities of larger specimens to accelerate penetration of formalin to preserve gut contents.

Tab. 1. Physical and chemical characteristics measured for Charcote and Charcotico during four survey periods. DO was not measured during November and December. January was the low-water period, September was near the peak of the annual flood pulse, and during November and December floodwaters were gradually receding.

\begin{tabular}{|c|c|c|c|c|c|c|c|c|}
\hline \multirow{2}{*}{ Parameter } & \multicolumn{2}{|c|}{ September } & \multicolumn{2}{|c|}{ November } & \multicolumn{2}{|c|}{ December } & \multicolumn{2}{|c|}{ January } \\
\hline & Charcotico & Charcote & Charcotico & Charcote & Charcotico & Charcote & Charcotico & Charcote \\
\hline Water temperature $\left({ }^{\circ} \mathrm{C}\right)$ & 28 & 27 & 27 & 28 & 26 & 27.5 & 29 & 30 \\
\hline Air temperature $\left({ }^{\circ} \mathrm{C}\right)$ & 30 & 26 & 28 & 27 & 30.5 & 30 & 26 & 34 \\
\hline $\mathrm{pH}$ & 5.5 & 5.5 & 6 & 5 & 5.5 & 5.5 & 5.5 & 5.75 \\
\hline Water velocity $(\mathrm{m} / \mathrm{s})$ & 0.12 & 0.45 & 0.39 & 0.39 & 0.3 & 0.39 & 0 & 0 \\
\hline DO (mg/L) & 6 & 6 & - & - & - & - & 5 & 4 \\
\hline Max. water depth (m) & 1.22 & 2.27 & 1.16 & 2.15 & 1.1 & 1.65 & 0.5 & 1.25 \\
\hline$\%$ Aquatic vegetation & 0 & 0 & 0 & 50 & 0 & 75 & 0 & 20 \\
\hline \% Canopy cover & 4 & 5 & 5 & 5 & 2 & 3 & 2 & 0 \\
\hline Secchi depth (m) & 1.22 & 2.27 & 1.16 & 2 & 0.5 & 0.4 & 0.2 & 0.35 \\
\hline
\end{tabular}


Stomach contents analysis. Fish specimens from each sample were sorted, identified to species and counted for calculation of species relative abundances in each monthly sample and site. Specimens were weighed using a triple beam balance with $0.1 \mathrm{~g}$ precision. Voucher specimens of each species were deposited in the Museo de Historia Natural de UNELLEZ, Guanare, Portuguesa, Venezuela.

Stomach contents analysis was performed using the methods of Winemiller (1990). The analysis was conducted on at least 30 individuals of each species per sample when available. Because their stomachs frequently were empty, all available specimens of piscivorous species were dissected for stomach contents. More than 60 specimens of the most abundant species (mostly characids) were dissected from each survey and location (S1 - Available only as online supplementary file accessed with the online version of the article at http://www.scielo.br/ni). Each specimen was dissected and the anterior half of the gut was removed for examination. Fish prey were identified to species whenever possible. Attempts were made to classify insects, crustaceans and other invertebrates to taxonomic order. Prey items that could not be identified to order, were recorded as higher taxonomic or functional groups. Materials taken from the gut were identified with a dissecting microscope or compound microscope. Larger prey items were blotted dry and their volumes were measured by water displacement in a graduated cylinder. Resolution using the graduated cylinder was $0.005 \mathrm{ml}$. For volumes less than $0.005 \mathrm{ml}$, items were spread on a glass slide and volume was estimated via comparison with a prepared slide on which there was a similarly spread substance measuring $0.005 \mathrm{ml}$.

Data analysis. Monthly variation in fish assemblage structure was assessed using constrained ordination. Fish abundance data were squared-root transformed and a canonical-correlation analysis (CCA) was performed using sampling months as a constraining variable. Species with relative abundance lower than $0.5 \%$ was excluded from this analysis. The influence of seasonality on fish assemblage structure was tested using an ANOVA like permutation test for Constrained Correspondence Analysis (1000 permutations; Legendre et al., 2011). We also tested the correlation between seasonal variation in fish assemblage structure and variation in food items ingested using a twoway MANTEL test (1000 permutations). The MANTEL test, CCA and ANOVA like permutation test were carried out using the R package vegan (Oksanen et al., 2017). To test our hypothesis that the abundance ratio of piscivores to nonpiscivores increases during the dry season, we calculated the ratio between numerical abundances of piscivorous and non-piscivorous fishes for each stream and survey month. Since several piscivorous species had diets containing fish plus other food resources, we classified piscivores as those species with more than $50 \%$ fish in their diet. These species were Acestrorhynchus spp., Acaronia vultuosa Kullander, 1989, Cichla orinocensis Humboldt, 1821, Crenicichla sp., Hoplias malabaricus (Bloch, 1794), Hoplerythrinus unitaeniatus (Spix \& Agassiz, 1829), Pimelodella sp. and Rhamdia sp.

Proportions of prey items consumed by all specimens at each location in each collection were used to calculate overall food resource diversity, using Simpson's (1949) formula: $\mathrm{D}=1 / \sum \mathrm{p}_{\mathrm{i}}^{2}$, where $\mathrm{p}_{\mathrm{i}}$ is the proportion of prey $i$ consumed by all species at a site. Large samples are required for accurate characterization of diet via stomach content analyses. For the analyses described below, we excluded rare species comprising less than $5 \%$ of the total number of individuals collected during a given sampling period at a given site (Winemiller, 1990). To calculate interspecific dietary overlap, Pianka' (1974) formula for symmetrical niche overlap was used: $\varphi_{\mathrm{jk}}=\varphi_{\mathrm{kj}}=\sum p_{i j} p_{i k} / \sqrt{\sum p_{i j}^{2} \sum p_{i k}^{2}}$, where $\mathrm{p}_{\mathrm{ij}}$ is the proportion of prey $i$ consumed by predator $j$, and $\mathrm{p}_{\mathrm{ik}}$ is the proportion of prey $i$ consumed by predator $k$. We used a program that calculates dietary overlap between all possible species pairs, and then computes the average overlap for each species' nearest neighbor in rank order. Overlap trends within assemblages cannot be compared using standard parametric statistics, because these values are not independent (Winemiller, Pianka, 1990). We therefore employed the null model of Winemiller, Pianka (1990) to test for significant non-random patterns of dietary overlap. We use their conserved-zeros matrix randomization algorithm that tests for non-random resource segregation within guilds. Significant resource segregation is inferred $(\alpha=0.05)$ when the observed overlap value is less than $95 \%$ of values generated by the null model, based on comparisons for all nearest neighbor ranks.

The relative abundance (RA) and frequency of occurrence (FO) of food items were calculated. For RA, we used volume of food items instead of numerical abundance to avoid overestimating the importance of small food items (e.g., microalgae, microcrustacea). To evaluate the dominance of different food items consumed by fishes in each stream during each survey period, FO was plotted against RA (Costello, 1990). To facilitate these comparisons, food categories were aggregated into six major groups: i) aquatic autotrophs (macrophytes, algae); ii) aquatic invertebrates; iii) detritus; iv) fish; v) terrestrial invertebrates; and vi) terrestrial vegetation (fruits, seeds, leaves, flowers). To evaluate temporal variation in consumption of allochthonous resources, FO and RA values for this category were summed and compared (herein called importance index).

The connectance of the trophic networks was measured using the formula (Pimm, 1982): $C=k n /[n(n-1)]=k /(n-1)$, where $k$ is the average number of species with which a given species interacts, $n$ is the number of species in the trophic network, and $n-1$ is the number of species with which an interaction is possible. Connectance was calculated on different data subsets based on three different criteria for the lower limit of trophic interaction strength for retention in the subset (i.e., link threshold, $\mathrm{LT}=0$ retains all volumetric proportion data, $p_{i j} ; \mathrm{LT}=0.01$ eliminates $\mathrm{p}_{\mathrm{ij}} \mathrm{s}<0.01$, and $\mathrm{LT}=$ 0.05 eliminates $\mathrm{p}_{\mathrm{ij}} \mathrm{s}<0.05$ ) (Winemiller, 1990). 


\section{Results}

During the four survey periods, 20,347 fish specimens representing 69 species were collected from the two streams (S1 - Available only as online supplementary file accessed with the online version of the article at http://www.scielo. br/ni), and most species occurred in both streams (65.2\%). Multivariate analysis and ordination revealed that seasonal within-site variation in assemblage structure generally was comparable to between-site variation within seasons (Fig. 2). CCA axis 1 was associated with seasonal variation (Fig. 2; (S2 - Available only as online supplementary file accessed with the online version of the article at http://www.scielo. $\mathrm{br} / \mathrm{ni}$ ), explained $31.7 \%$ of variation in assemblage structure (eigenvalue $=0.28)$ and was statistically significant $\left(\mathrm{F}_{(1,6)}=\right.$ $2.78 \mathrm{P}=0.004$ ). Axis 2 (eigenvalue $=0.23$, modeling $26.3 \%$ of total variation) was weakly associated with seasonal variation in the assemblage structure of Charcotico, but strongly differentiated the structure at Charcote during December (late falling water) and January (low water). Fish assemblage structures of the two streams were most similar during the high and early falling water periods
(Fig. 2). Species of Hemigrammus Gill, 1858, were the most abundant fishes in both streams and were particularly dominant during high- and falling-water periods (Fig. 2). Piscivorous species, such as Rhamdia sp., Hoplerythrinus unitaeniatus, Crenicichla sp. and Cichla orinocensis, tended to have greater relative abundance during the low-water period (positive values on CCA axis 1; Fig. 2). As predicted, the abundance ratio of piscivores to non-piscivores was greater during the low-water season (Fig. 3). In Charcotico, this ratio increased more than two orders of magnitude from November to January, and in Charcote it increased more than three orders of magnitude during this period.

Empty stomachs were found for 636 specimens, $14 \%$ out of the 4,516 fish specimens dissected (S1 and $\mathbf{S 3}$ - Available only as online supplementary file accessed with the online version of the article at http://www.scielo.br/ni). Seasonal variation in fish assemblage structure was correlated with seasonal variation in food items ingested (MANTEL; $r=0.58$ $\mathrm{P}=0.02$ ). Dietary diversity varied seasonally (Fig. 3 ), with a decline from November (early falling-water period) to January (low water) in both streams $(71.1 \%$ decline in Charcotico; $52.1 \%$ decline in Charcote), which supported our prediction.

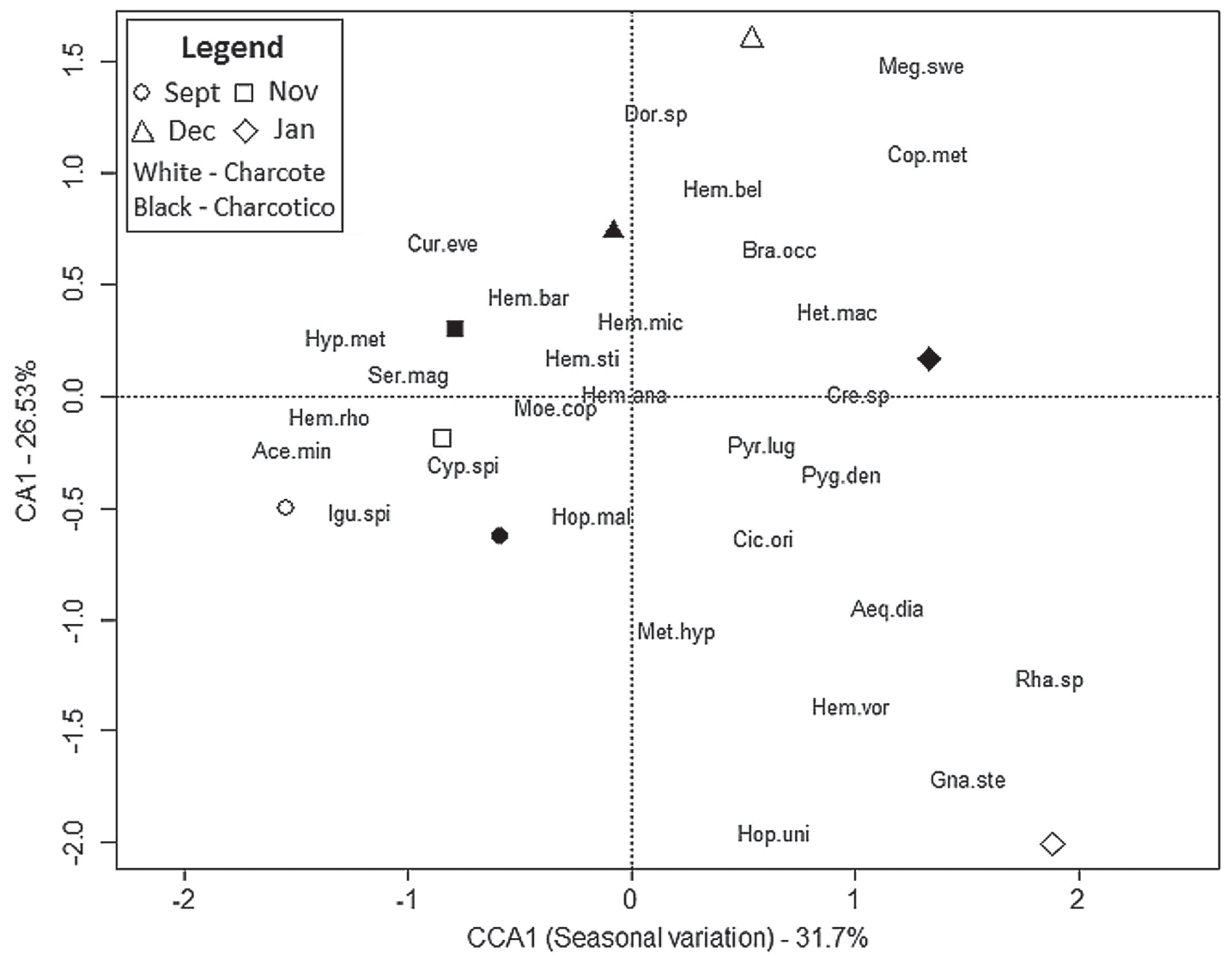

Fig. 2. Canonical Correspondence Analysis (CCA) for the fish assemblage structure sampled during four months (symbols) in the Charcote (white) and Charcotico (black) streams. Only species with more than $0.5 \%$ of abundance were included in this analysis. For graphical purposes, we are only showing species that had a goodness-of-fit larger than 0.1. A list with species' abbreviations and species and sites scores can be found in ( $\mathbf{S 2}$ - Available only as online supplementary file accessed with the online version of the article at http://www.scielo.br/ni). The low-water period is represented by January, high water by September, and falling water by November and December. 


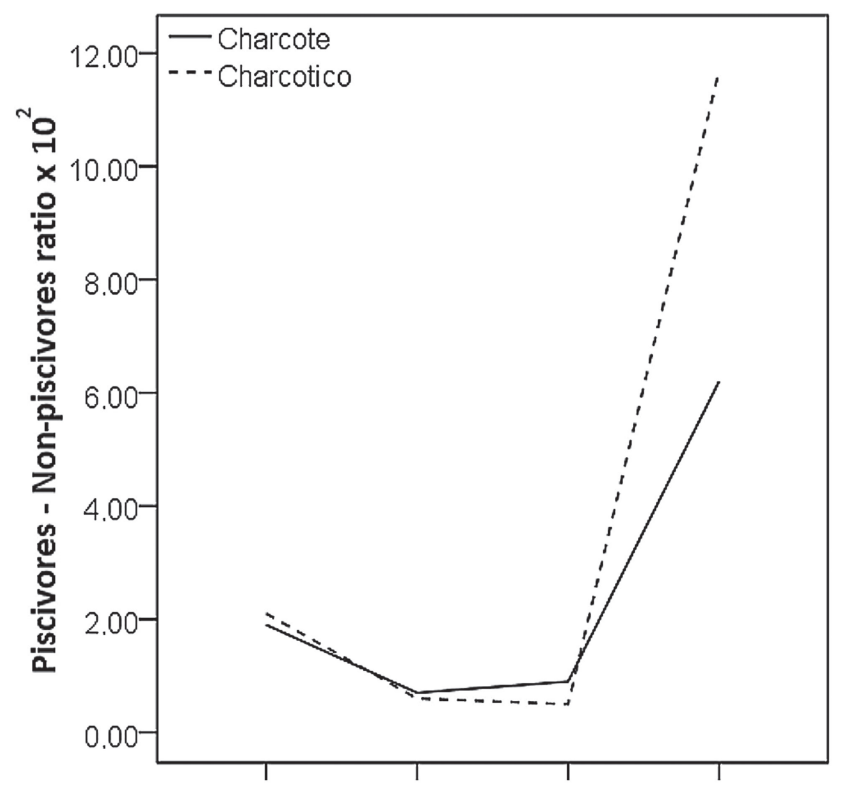

Tab. 2. Mean dietary overlap among fish species in two Venezuelan Llanos streams (Charcote and Charcotico) collected during four survey periods. Values in parentheses are standard deviations (SD). Pseudo-communities > Real communities indicates the proportion of pseudocommunities with mean overlap values higher than the mean value recorded for the community $(\%)$. P values were based on comparison with null model calculations (pseudo-communities), and values lower than 0.05 indicate significant resource segregation among species. January was the low-water period, September was near the peak of the annual flood pulse, and during November and December floodwaters were gradually receding.

\begin{tabular}{ccccc}
\hline Site & Month & Mean overlap & $\begin{array}{c}\text { Pseudo-communities } \\
\text { Real communities }\end{array}$ & P value \\
\hline Charcote & September & $0.08(0.115)$ & 80 & $\mathrm{P}<0.05$ \\
Charcote & November & $0.11(0.177)$ & 100 & $\mathrm{P}<0.05$ \\
Charcote & December & $0.12(0.131)$ & 97 & $\mathrm{P}<0.05$ \\
Charcote & January & $0.14(0.166)$ & 100 & $\mathrm{P}<0.05$ \\
\hdashline Charcotico & September & $0.12(0.130)$ & 86 & $\mathrm{P}<0.05$ \\
Charcotico & November & $0.11(0.141)$ & 100 & $\mathrm{P}<0.05$ \\
Charcotico & December & $0.12(0.143)$ & 100 & $\mathrm{P}<0.05$ \\
Charcotico & January & $0.11(0.161)$ & 93 & $\mathrm{P}<0.05$ \\
\hline
\end{tabular}

Allochthonous resources were relatively uncommon in fish diets in both streams (Fig. 4). Overall, Charcote fishes consumed more terrestrial invertebrates during September (high water) than other months as predicted (Fig. 4). More terrestrial vegetation was consumed during December (falling water). In contrast, fishes in Charcotico collectively consumed similar amounts of terrestrial invertebrates during various survey periods, and contrary to our expectations, consumption of terrestrial vegetation peaked during January (low water; Fig. 4). Aquatic invertebrates were the most frequently consumed food items in both rivers, except during the low-water period (January) when aquatic autotrophs were more frequently consumed. Consumption of aquatic autotrophs was greater in Charcote than Charcotico. Detritus had relatively low importance as a direct food resource for fishes in both streams, although there was a decrease in detritus FO in stomachs during the late stages of the low-water period in Charcotico. In both streams, fish was the diet category consumed in greatest volumes, and piscivory was greatest in both streams during the low-water period (January).

Average interspecific dietary overlap increased as water levels dropped over time in Charcote, but revealed less seasonal variation in Charcotico (Tab. 2). Thus, these results did not corroborate our hypothesis that dietary overlap is lowest during the low-water period. Based on comparisons with null model simulations, average observed dietary overlap indicated significant dietary segregation among fishes in both streams during all periods (Tab. 2; S4 - Available only as online supplementary file accessed with the online version of the article at http://www.scielo.br/ni).

Our prediction that food web connectance would increase during the low-water period was not supported by the data (Tab. 3). Average food web connectance was similar for Charcote and Charcotico $(\sim 0.035, \mathrm{SD}=0.002$ vs. $\sim 0.037, \mathrm{SD}=0.002$, respectively). Although mean connectance decreased with increasing link threshold, low temporal variation in connectance was consistent for all link threshold values examined (Tab. 3). 

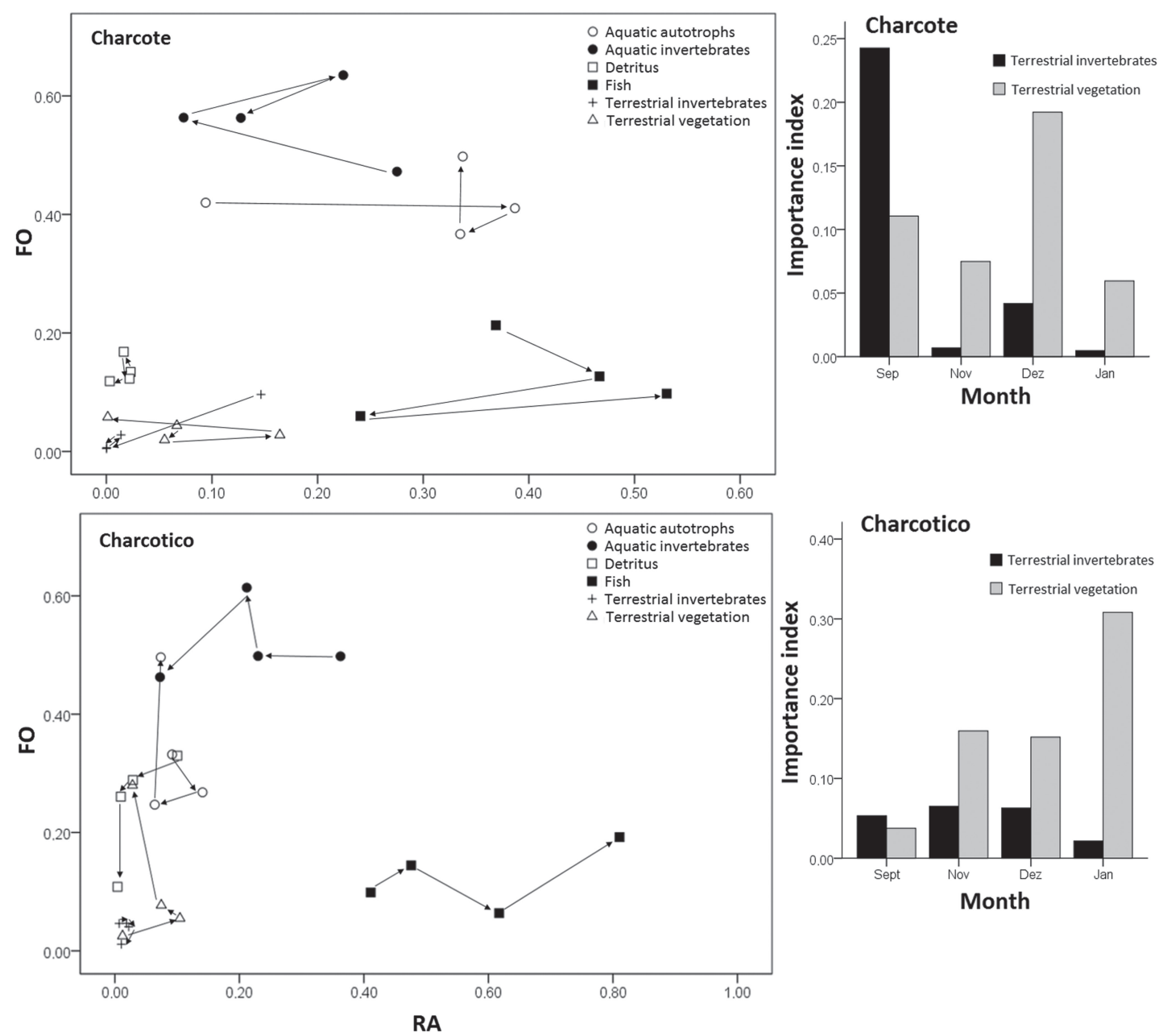

Fig. 4. Scatterplots (modified Costello diagram) showing the frequency of occurrence (FO) and relative abundance (RA) of prey items ingested by the entire fish assemblage in the Charcote (upper) and Charcotico (bottom) streams. Arrows indicate changes in the FO and RA of food items between months. Symbols indicate different types of food items. Bar charts (right side) highlight variation in the importance (FO+RA) of allochthonous materials (terrestrial invertebrates and vegetation) in fish diets. The lowwater period is represented by January, high water by September, and falling water by November and December.

Tab. 3. Connectance of fish trophic networks in two Venezuelan Llanos streams during four survey periods. LT= link threshold, which defines the lower limit of the magnitude of trophic interactions (represented by proportional volume of dietary items in the diet of a given consumer during a given period) included in the connectance estimate. January was the low-water period, September was near the peak of the annual flood pulse, and during November and December floodwaters were gradually receding.

\begin{tabular}{ccccc}
\hline \multirow{2}{*}{ Stream } & \multirow{2}{*}{ Month } & \multicolumn{3}{c}{ Connectance } \\
\cline { 3 - 5 } Charcote & LT=0 & LT $=0.01$ & LT $=0.05$ \\
\hline \multirow{7}{*}{ Charcotico } & September & 0.036 & 0.030 & 0.018 \\
& November & 0.033 & 0.026 & 0.018 \\
& December & 0.038 & 0.034 & 0.021 \\
& January & 0.035 & 0.028 & 0.019 \\
& September & 0.039 & 0.033 & 0.018 \\
& November & 0.037 & 0.030 & 0.019 \\
& December & 0.038 & 0.031 & 0.020 \\
& January & 0.035 & 0.024 & 0.017 \\
\hline
\end{tabular}

\section{Discussion}

We found a strong influence of seasonal hydrological variation on assemblage structure and trophic interactions of freshwater fishes in both streams. Although some environmental and assemblage features varied between the two streams, their food webs had similar species composition, average dietary overlap, collective exploitation patterns of food resource categories, and connectance (realized proportion of possible consumerresource interactions).

Fish assemblage structures of the two streams were most divergent during the low-water period. This result is consistent with findings from other studies of floodplain fish assemblages, wherein beta diversity was higher during the low-water season when aquatic habitats become more isolated and local environmental conditions strongly influence local community structure (Tab. 1; Thomaz et al., 2007). Consequently, species sorting should be 
important for local community assembly during the lowwater season, resulting in reduced among-site similarity in assemblage structure (Scarabotti et al., 2011). During the annual flood pulse, there is greater spatial connectivity of aquatic habitats, and mass effects (i.e., dispersal) should have a stronger influence on local community assembly. Moreover, environmental conditions tend to be more similar among water bodies during the high-water period (Thomaz et al., 2007). Greater dispersal and habitat similarity may yield greater among-site similarity in fish assemblage structure. This spatiotemporal variation in resource availability and fish assemblage structure of floodplain streams creates dynamic networks of consumerresource interactions (Winemiller, 1990).

Perennial pools within streams draining the Llanos may serve as dry-season refugia for diverse fishes (Magoulick, Kobza, 2003; Beesley, Prince, 2010). As these pools shrink and become isolated, the relative abundance of piscivores generally increases, and this was the pattern observed in Charcote and Charcotico. The piscivore-nonpiscivore abundance ratio in our samples was markedly higher during the low-water season. However, not every piscivore species increased, and exceptions were Hoplias malabaricus, which had similar relative abundance during every survey period, and Acestrorhynchus spp., which was more common during the high-water period (Fig. 3). Higher piscivore relative abundance during the low-water period also could have been influenced by immigration of piscivorous fishes seeking to exploit prey that initially have high densities within shrinking aquatic habitat. With influx of piscivores, prey populations have higher predation mortality and population decline (Winemiller, 1989; Jepsen et al., 1997). Abundance of Hemigrammus spp. and several other important prey fishes in these habitats decreased during the low-water period, probably due to predation by piscivorous fishes as well as birds that are also attracted to this type of habitat (for more details see Gawlik, 2002; Keppeler et al., 2016). Greater relative abundance of piscivores during the low-water period could result in stronger top-down regulation in food webs (e.g., Layman, Winemiller, 2004), a topic that merits additional study in tropical streams.

As hypothesized, average dietary diversity decreased from wet to dry periods in both streams. In a study of fishes in a tropical stream in Panamá, Zaret, Rand (1971) found that fishes generally had broader trophic niches during the wet season when availability of most food resources increased. Aquatic habitat reduction during the dry season was likely the main driver of the decline in the diversity of foods ingested by fishes in these Llanos streams; smaller aquatic habitats generally harbor fewer organisms and species (Angermeier, Schlosser, 1989; McCabe, Gotelli, 2000; Anjos, Zuanon, 2007). At the same time, higher perunit-area fish densities during the low-water period probably depleted the abundance and richness of some aquatic invertebrates that are major contributors to fish diets.
In both streams during all periods, average interspecific dietary overlap was lower than expected by chance. Although many of these species are omnivorous with relatively broad diets, this suggests that they nonetheless partition food resources, an inference made by studies of other tropical streams (Winemiller, 1989, 1990; Winemiller, Pianka, 1991; Herder, Freyhof, 2006; Silva et al., 2012). Interspecific dietary overlap tended to increase in Charcote as the dry season progressed, but average dietary overlap varied little in Charcotico. The hypothesis that reduced aquatic habitat and lower availability of food resources results in lower dietary overlap is therefore rejected in this instance and it remains unclear why the two streams showed different seasonal patterns of interspecific dietary overlap. Liem's paradox addresses unanticipated observations of high dietary overlap among species with divergent morphology, behavior and/ or physiology (Robinson, Wilson, 1998), and may apply to fishes in these streams. The discrepancy in the seasonal changes of dietary overlap between the two streams suggests that additional factors not examined here, such as variation in primary productivity or predation threat, also affect fish trophic ecology in these streams.

Results did not support the hypothesis that fishes consume more allochthonous food resources during the high-water period when fishes have greater access to riparian areas. Only Charcote fishes showed greater consumption of terrestrial invertebrates during the high-water period. Allochthonous resources contributed relatively little to fish diets during the other survey periods at both sites. This finding contrasts with those from studies of oligotrophic rivers in the Amazon where allochthonous food items have been shown to be important in fish diets (Goulding et al., 1988; Correa, Winemiller, 2014). Limited entry of allochthonous resources into the food web of streams in the Central Llanos region may be due, in part, to landscapes dominated by grasslands rather than forests. Forest density has been shown to be a good predictor for the importance of allochthonous items in fish diets in other Neotropical systems (Abilhoa et al., 2010; Keppeler et al., 2013). In addition to supporting terrestrial plant and animal biomass entering aquatic habitats, forests also block solar irradiance and, consequently, reduce autochthonous primary production, including phytoplankton and aquatic macrophytes (Goulding et al., 1988). However, the importance of allochthonous material for aquatic food webs in Llanos streams cannot be discounted, because terrestrial biomass probably supports many basal consumers, such as shrimps and other aquatic macroinvertebrates, as well as decomposers involved in nutrient recycling (Vannote et al., 1980). Research using stable isotope or biochemical methods of analysis could elucidate the fate of allochthonous organic material entering tropical streams.

In both streams, most fishes consumed aquatic invertebrates, a finding consistent with those from studies of streams in other tropical regions (Deus, Petrere-Junior, 2003; Bonato et al., 2012; Dudgeon et al., 2010). Although most piscivorous tropical fishes are also capable of feeding 
on aquatic invertebrates, especially during early life stages (Winemiller, 1989), our data reveal a trend whereby proportions of aquatic invertebrates and fish in diets were inversely associated (Fig. 4). Although this inverse relationship could be explained by ontogenetic dietary differences, another explanation is that reduced availability of invertebrate prey results in a density-dependent increase in piscivory.

Aquatic macrophytes and algae were the most frequently consumed basal resources, and detritivory by fish was uncommon in both streams (Fig. 4). The latter finding contrasts with those from food-web studies of temperate streams (Cummins et al., 1966; Minshall, 1967; Hildrew et al., 1985) and other tropical streams (Winemiller, 1990); however, studies of desert stream communities found greater reliance on algae than detritus by metazoan consumers (Fisher, 1986). Charcote and Charcotico fishes ingested more aquatic autotrophs during the low-water period when stream flow was lowest and aquatic macrophyte biomass (and probably periphyton biomass on macrophyte surfaces) was greatest.

Food-web connectance was essentially the same in the two streams, with little seasonal variation. This result refutes our hypothesis that food-web connectance increases during the low-water period, when densities of aquatic organisms increase and predator-prey interactions should become more frequent. Winemiller (1990) also found only minor differences in food-web connectance in streams of the Western Llanos region that experience major changes in environmental conditions and fish assemblage composition between wet and dry seasons. Connectance values for Charcote and Charcotico were low compared to values reported for other terrestrial and aquatic food webs, some with estimates as high as 4 (Hewatt, 1937; Paine, 1966, 1980; Menge, Sutherland, 1976; Dunne et al., 2002). Schmid-Araya et al. (2002) concluded that connectance of stream food webs is lower than in other types of ecosystems. Low connectance of stream food webs may be associated with body size disparity within food chains, disturbance associated with flow variation, and heterogeneity and complexity of stream habitats (Schmid-Araya et al., 2002). Differences between connectance of our trophic networks based on fish diets and connectance values reported in studies that analyzed published food web diagrams could be methodological artifacts; for example, our food webs have many nodes but lack trophic links between invertebrates and their food resources, and most published food web diagrams contain few nodes, with many nodes consisting of highly aggregated taxa or functional groups (Paine, 1988; Winemiller, 1990; Cohen et al., 1993).

Food web studies, both theoretical and empirical, have increased substantially in recent decades (Layman et al., 2015), but research that examines temporal variation using standard methodologies are uncommon. We analyzed fish diets based on large samples to examine changes in trophic ecology and food webs of two tropical streams with strong seasonal hydrology. As expected, we found that the abundance ratio of piscivores to non-piscivores increased greatly during the low-water season. Similarly, our hypothesis that average dietary diversity declines as food resources become increasingly scarce during the low-water season was supported. Conversely, we did not find strong support for our hypotheses regarding seasonal patterns of interspecific dietary overlap, fish exploitation of allochthonous resources, and food web connectance. Interspecific dietary overlap increased slightly during the low-water season in one stream with negligible changes in the other. Allochthonous resources tended to be uncommon in fish diets during both seasons. Food web connectance was essentially the same in the two streams, with little seasonal variation. Our empirical findings provide much-needed data on the trophic ecology of little-studied, tropical freshwater fishes, and should be useful for modeling food web structure and dynamics in tropical streams.

\section{Acknowledgments}

Fish collections were conducted under scientific permit 1194 issued by the Ministerio de Agricultura y Cria, Servicio Autonomo de los Recursos Pesqueros y Acuicolas, Republica de Venezuela. Permission for collecting in Aguaro-Guariquito National Park was granted by EMPARQUES de Venezuela. We thank Donald Taphorn and the Universidad de los Llanos Occidentales Esequiel Zamora for administrative and logistical support, and Tony Rodger for assistance during preparation of the manuscript. FWK thanks Ministry of Education of Brazil for support from a CAPES Foundation scholarship, and KOW acknowledges support from NSF grant DEB1256090 during preparation of the manuscript.

\section{References}

Abilhoa V, Vitule JRS, Bornatowski H. Feeding ecology of Rivulus luelingi (Aplocheiloidei: Rivulidae) in a Coastal Atlantic Rainforest stream, southern Brazil. Neotrop Ichthyol. 2010; 8(4):813-18.

Angermeier PL, Schlosser IJ. Species-area relationship for stream fishes. Ecology. 1989; 70(5):1450-62.

Arrington DA, Winemiller KO, Layman CA. Community assembly at the patch scale in a species rich tropical river. Oecologia. 2005; 144(1):157-67.

Anjos MB, Zuanon J. Sampling effort and fish species richness in small terra firme forest streams of central Amazonia, Brazil. Neotrop Ichthyol. 2007; 5(1):45-52.

Beesley LS, Prince J. Fish community structure in an intermittent river: the importance of environmental stability, landscape factors and within-pool habitat descriptors. Mar Freshw Res. 2010; 61(5):605-14.

Bonato KO, Delariva RL, Silva JC. Diet and trophic guilds of fish assemblages in two streams with different anthropic impacts in the northwest of Paraná, Brazil. Zoologia. 2012; 29(1):27-38. 
Buren AD, Koen-Alonso M, Montevecchi WA. Linking predator diet and prey availability: common murres and capelin in the Northwest Atlantic. Mar Ecol Prog Ser. 2012; 445(1):25-35.

Cohen JE, Beaver RA, Cousins SH, DeAngelis DL, Goldwasser L, Heong KL et al. Improving food webs. Ecology. 1993; 74(1):252-58.

Correa SB, Winemiller KO. Niche partitioning among frugivorous fishes in response to fluctuating resources in the Amazonian floodplain forest. Ecology. 2014; 95(1):210-24.

Costello MJ. Predator feeding strategy and prey importance: a new graphical analysis. J Fish Biol. 1990; 36(2):261-63.

Cummins KW, Coffman WP, Roff PA. Running waters: trophic relationships in a small woodland stream. Verh Internat Verein Limnol. 1966; 16:627-38.

Deus CP, Petrere-Junior M. Seasonal diet shifts of seven fish species in an Atlantic rainforest stream in Southeastern Brazil. Braz J Biol. 2003; 63(4):579-88.

Dudgeon D, Cheung FKW, Mantel SK. Food web structure in small streams: do we need different models for the tropics? J North Am Benthol Soc. 2010; 29(2):395-412.

Dunne JA, Williams RJ, Martinez ND. Food-web structure and network theory: the role of connectance and size. Proc Natl Acad Sci USA. 2002; 99(20):12917-22.

Emlen JM. The role of time and energy in food preference. Am Nat. 1966; 100(916):611-17.

Fisher SG. Structure and dynamics of desert streams. In: Whitford WG, editor. Pattern and process in desert ecosystems. Albuquerque: University of New Mexico Press; 1986. p.119-39.

Gawlik DE. The effects of prey availability on the numerical response of wading birds. Ecol Monogr. 2002; 72(3):329-46.

Goulding M, Carvalho ML, Ferreira EG. Rio Negro, rich life in poor water. The Hague: SPB Academic Publishing; 1988.

Henderson PA. Fish of the Amazonian Igapó: stability and conservation in a high diversity-low biomass system. J Fish Biol. 1990; 37(Suppl.A):61-66.

Herder F, Freyhof J. Resource partitioning in a tropical stream fish assemblage. J Fish Biol. 2006; 69(2):571-89.

Hewatt WG. Ecological studies on selected marine intertidal communities of Monterey Bay California. Ecol Monograph. 1937; 18(2):161-206.

Hildrew AG, Townsend CR, Hasham A. The predatory Chironomidae of an iron-rich stream: feeding ecology and food web structure. Ecol Entomol. 1985; 10(4):403-13.

Jepsen DB, Winemiller KO, Taphorn DC. Temporal patterns of resource partitioning among Cichla species in a Venezuelan blackwater river. J Fish Biol. 1997; 51(6):1085-108.

Junk WJ, Bayley PB, Sparks RE. The flood pulse concept in riverfloodplain systems. In: Dodge DP, editor. Proceedings of the International Large River Symposium. Can Spec Publ Fish Aquat Sci: Canadian Government Publishing Centre/Canada Communication Group; 1989. p.110-27.

Keppeler FW, Cruz DA, Dalponti G, Mormul RP. The role of deterministic factors and stochasticity on the trophic interactions between birds and fish in temporary floodplain ponds. Hydrobiologia. 2016; 773(1):225-40.
Keppeler FW, Lanés LEK, Rolon AS, Stenert C, Maltchik L. The diet of Cynopoecilus fulgens Costa, (Cyprinodontiformes: Rivulidae) in Southern Brazil wetlands. Ital J Zool. 2013; 80(2):291-302

Kie JG, Bowyer RT. Sexual segregation in white-tailed deer: density-dependent changes in use of space, habitat selection, and dietary niche. J Mammal, 1999; 80(3):1004-20.

Layman CA, Winemiller KO. Size-based response of prey to piscivore exclusion in a species-rich Neotropical river. Ecology. 2004; 85(5):1311-20.

Layman CA, Giery ST, Buhler S, Rossi R, Penland T, Henson MN, Bogdanoff AK, Cove MV, Irizarry AD, Schalk CM, Archer SK. A primer on the history of food web ecology: fundamental contributions of fourteen researchers. Food Webs. 2015; 4:1424.

Legendre P, Oksanen J, ter Braak CJF. Testing the significance of canonical axes in redundancy analysis. Methods Ecol Evol. 2011; 2(3):269-77.

Lowe-Mcconnell R. Ecological studies in tropical fish communities. London: Cambridge University Press; 1987.

Magoulick DD, Kobza RM. The role of refugia for fishes during drought: a review and synthesis. Freshwater Biol. 2003; 48(7):1186-98.

McCabe DJ, Gotelli NJ. Effects of disturbance frequency, intensity, and area on assemblages of stream macroinvertebrates. Oecologia. 2000; 124(2):270-79.

McCann KS. Food webs. New Jersey: Princeton University Press; 2011.

McMeans BC, McCann KS, Humphries M, Rooney N, Fisk AT. Food web structure in ecosystems. Trends Ecol Evol. 2015; 30(11):662-72.

Menge BA, Sutherland JP. Species diversity gradients: synthesis of the roles of predation, competition, and temporal heterogeneity. Am Nat. 1976; 110(973):351-69.

Mérona B, Rankin-de-Mérona J. Food resource partitioning in a fish community of the central Amazon floodplain. Neotrop Ichthyol. 2004; 2(2):75-84.

Minshall GW. Role of allochthonous detritus in the trophic structure of a woodland springbrook community. Ecology. 1967; 48(1):139-49.

Montes RA, San-José J, Aymard GA. Characteristics of the Flora and vegetation of the Mesa high plain and the eolic plain at the Aguaro Guariquito National Park, Guárico State, Venezuela. Caldasia. 2013; 35(2):1-12.

Oksanen J, Kindt R, Legendre P, O’Hara B, Simpson GL, Solymos P, Stevens MHH, Wagner H. Vegan: community ecology package [Internet]. 2017 [updated 2017 April 7; cited 2017 April 1]. Available from: CRAN.R-project.org/package=vegan

Paine RT. Food web complexity and species diversity. Am Nat. 1966; 100(910):65-75.

Paine RT. Food webs: linkage, interaction strength and community infrastructure. J Anim Ecol. 1980; 49(3):666-85.

Paine RT. On food webs: road maps of interactions or the grist for theoretical development? Ecology. 1988; 69(6):1648-54.

Pianka ER. Niche overlap and diffuse competition. PNAS. 1974; 71(5):2141-45. 
Pimm SL. Food webs. London: Chapman; 1982.

Polis GA. Complex trophic interactions in deserts: an empirical critique of food-web theory. Am Nat. 1991; 138(1):123-55.

Robinson BW, Wilson DS. Optimal foraging, specialization, and a solution to Liem's paradox. Am Nat. 1998; 151(3):223-35.

Rooney N, McCann KS, Moore JC. A landscape theory for food web architecture. Ecol Lett. 2008; 11(8):867-81.

Scarabotti PA, López JA, Pouilly M. Flood pulse and the dynamics of fish assemblage structure from neotropical floodplain lakes. Ecol Freshw Fish. 2011; 20(4):605-18.

Schmid-Araya JM, Schmid PE, Robertson A, Winterbottom J, Gjerløv C, Hildrew AG. Connectance in stream food webs. J Anim Ecol. 2002; 71(6):1056-62.

Schoener TW. Theory of feeding strategies. Annu Rev Ecol Syst. 1971; 2:369-404.

Siepielski AM, Fallon E, Boersma K. Predator olfactory cues generate a foraging - predation trade-off through prey apprehension. R Soc Open Sci. 2016; 3:150537. DOI: 10.1098/ rsos. 150537

Silva JC, Delariva RL, Bonato KO. Food-resource partitioning among fish species from a first-order stream in northwestern Paraná, Brazil. Neotrop Ichthyol. 2012; 10(2):389-99.

Simpson EH. Measurement of diversity. Nature. 1949; 163(30 April):688-88.

Stuart-Smith RD, Richardson AMM, White RWG. 2004. Increasing turbidity significantly alters the diet of brown trout: A multiyear longitudinal study. J Fish Biol. 65(2):376-88.

Thomaz SM, Bini LM, Bozelli RL. Floods increase similarity among aquatic habitats in river-floodplain systems. Hydrobiologia. 2007; 579(1):1-13.

Thompson RM, Townsend CR. The effect of seasonal variation on the community structure and food-web attributes of two streams: implications for food-web science. Oikos. 1999; 87(1):75-88

Vannote RL, Minshall GW, Cummins KW, Sedell JR, Cushing CE. The river continuum concept. Can J Fish Aquat Sci. 1980; 37(1):130-37.
Werner EE, Hall DJ. Ontogenetic habitat shifts in bluegill : the foraging rate-predation risk trade-off. Ecology. 1988; 69(5):1352-66.

Williams RJ, Martinez ND. Simple rules yield complex food webs. Nature. 2000; 404(9 March):180-83.

Winemiller KO. Ontogenetic diet shifts and resource partitioning among piscivorous fishes in the Venezuelan Llanos. Environ Biol Fishes. 1989; 26(3):177-99.

Winemiller KO. Spatial and temporal variation in tropical fish trophic networks. Ecol Monogr. 1990; 60(3):331-67.

Winemiller KO. Factors driving temporal and spatial variation in aquatic floodplain food webs. In: Polis GA, Winemiller KO, editors. Food webs: Integration of patterns and dynamics. New York: Chapman and Hall; 1996. p.298-312.

Winemiller KO, Jepsen DB. Efects of seasonality and fish movement on tropical river food webs. J Fish Biol. 1998; 53(Suppl.A):267-96.

Winemiller KO, Pianka ER. Organization in natural assemblages of desert lizards and tropical fishes. Ecol Monograph. 1990; 60(1):27-55

Winemiller KO, Pianka ER, Vitt LJ, Joern A. Food web laws or niche theory? Six independent empirical tests. Am Nat. 2001; 158(2):193-99.

Yodzis P, Winemiller KO. In search of operational trophospecies in a tropical aquatic food web. Oikos. 1999; 87(2):327-40.

Zaret TM, Rand AS. Competition in tropical stream fishes: support for the competitive exclusion principle. Ecology. 1971; 52(2):336-42.
Submitted September 06, 2016 Accepted April 25, 2017 by Rosemara Fugi 
